\title{
The Relationship among the Motivation for I-Ching Learning, Life and Family Satisfaction in a Lifelong Learning Program of I Ching University
}

\author{
Chen-Mei Li, PhD \\ Weixin Shengjiao College \\ Li-Yueh Chen, PhD \\ Weixin Shengjiao College \\ No.667, Ln. 705, Wenhua Rd., Nantou City \\ Nantou County 540, Taiwan
}

\begin{abstract}
The purpose of this study is to explore how adult perform high level of learning motivation in I-Ching study, which facilitates life satisfaction and family satisfaction. I Ching University is the pioneer of lifelong learning in Taiwan. The University as the case to study, the results indicated that (1) Female responders in both family togetherness of learning motivation and overall learning motivation were significantly higher than male responders. (2) Age, family togetherness and social stimulation of learning motivation have a positive relationship. (3) Social contact, social stimulation, and cognitive interest of learning motivation have positive prediction effects on life satisfaction. (4) Social contact and cognitive interest of learning motivation and overall learning motivation have positive prediction effects on family satisfaction. Additionally, increasing the levels of social contact and cognitive interest of I-Ching learning motivation effectively facilitates life satisfaction and family satisfaction. Suggestions for research findings are also included.
\end{abstract}

Keywords: I-Ching education, Learning motivation, Life satisfaction, Family satisfaction

\section{Introduction}

In 2008, the US sub-prime mortgage-linked debt triggered a global economic crisis leading to the global outbreak of unemployment. According to Taiwan's Labor Quarterly (2009) reported that the 2008 financial crisis could influence the job market causing cyclical unemployment which could rapidly deteriorate and bring about widespread unemployment. This would affect the young and highly educated population. This could develop into a long-term issue affecting unemployment and would require attention in finding a solution to the problem. The statistical data from the Directorate General of Budget, Accounting and Statistics, Executive Yuan, R.O.C. showed that in 2008, the average number of unemployed people in Taiwan was 450,000 and the average number of weeks of unemployment was 25.3 weeks. Forty-five to sixty-four year olds had the highest unemployment rate among all age groups. The reduction of monthly family income visibly is putting pressure on family life and a source of social instability and worry. In additional, In December 2009, one of the world's three major credit rating agencies - Fitch Ratings downgraded Greece's credit rating, thus igniting the EU debt crisis that expanded to Portugal, Italy and Spain and other countries. The Economist magazine reported that Greece's financial problems spread to Portugal, Spain, and other countries, creating turmoil on the global financial market. Some Member States fear the problems in the financial market will cause some euro zones to become unstable and feel it will threaten economic stability.

In the eve of May 13, 2014, anti-Chinese riots took place in Vietnam, losing control of the situation, large crowds stormed into the Taiwanese industrial zone destroying and burning buildings and equipment. Vietnam has always been a significant place of investment for Taiwan in Southeast Asia. Soong Jenn-jaw (2014) pointed out that Taiwan's businesspersons were the most affected and suffered great loss during the riot. With a total of 2,287 Taiwanese investments in Vietnam, more than 224 companies were affected. According to the R.O.C. Ministry of Foreign Affairs, the total number of Taiwan businesspersons in Vietnam amounted to 40,000 people. Taiwan provided some 1.4 million jobs to the Vietnamese locals. The Taiwanese investment in Vietnam injected a lot of money and technology to the local economy, promoted local economic development and provided many jobs contributing to Vietnam's economic development. The individuals involved in the anti-Chinese riots in Vietnam not only lost their jobs but also destroyed the country's economic development. If international investors withdrew from Vietnam, the results would be catastrophic to the Vietnamese economy. In the systematic environment of society, the family does not exist alone but is part of a pulsating environment. 
In 2008, the global financial crisis led to a global unemployment problem, and then in 2009 Greece's fiscal problems occurred and spread to Portugal and Spain, and put the global financial market in turmoil. Then in 2014, the antiChinese riots occurred in Vietnam. All these derive from the financial, fiscal, political, economic and cultural environmental changes. This affects employment opportunities of individuals, thereby, affecting families' own resources and source of pressure. So, every individual should learn how to deal and cope with environmental change, this will aid individuals and their family to a large extent.

Lifelong learning has become significant in the shaping of national and international education policy, linked with both global economic competition and goals of equality and social cohesion (Holford et al., 2008). Research shows that motivated learners are more likely to undertake challenging activities, to be actively engaged, to enjoy and adopt a deep approach to learning, and to exhibit enhanced performance, persistence, and creativity (Schunk, et al., 2008). Jagodzinski (2009) has reported that life satisfaction is directly related to goals and wishes for today and the future, as well as personal expectations of reaching or fulfilling such goals. Research on family satisfaction is widely believed that both personality and interpersonal orientation are shaped by the crucible of the family. Family satisfaction is a person's felt experience of perception about the quality of the relationships and life within a family. The I-Ching is one of the oldest classics in China. It reveals three universal principles of life, that of Change, unchanging and simple change. The character 易 (I) contains three layers of meaning. Although the universe is in a constant state of change its essential principle is eternally unchanging. Whoever is able to understand and penetrate the simple words and deep meaning of the classics will use simple words to explain complicated things. By mastering and adhering to the principles, one can follow the right direction in life and attain a state where one is able to cope with constantly changing situations. I Ching University in Taiwan has contributed to promoting the Chinese culture I-Ching. However, the purpose of this study is to explore the relationship between the motivation for I-Ching learning, life satisfaction, and family satisfaction in the set of an adult lifelong learning system.

\section{The case: I Ching University}

The IChing University was founded in 1994. By adopting the way of religious education to promote lifelong learning, the University has been a pioneer of the lifelong education in Taiwan. The establishment of I Ching University was in part to carry forward the wisdom of the ancient sages of China and to inform our generations of the importance of our Chinese cultural heritage towards humanity. The meaning of I Ching University derives from a text called "the Great Learning (also called Da Xue)", this text indicated that "What the Great Learning teaches". What is call "Da Xue" does not only refers to an individual's scope of learning but includes learning reciprocally between two people, between a person and a group, between a person and society, and between a person and a nation. Learning to get along with each other, and all humankind. However, the idea of I Ching University has corresponded with the five pillars of lifelong learning, which was proposed by United Nations Educational, Science and Cultural Organization, UNESCO. The five pillars of learning consisted of learning to live together, learning to know, learning to do, learning to be, and learning to change.

The founder of I Ching University, Grand master Huan-yuan believe that the book of changes is a beacon of peace for the world. In 1985, Grand master Huan-yuan while discussing a passage in the I-Ching which clearly points out that the origin of the book of changes in China goes back 7000 years, and has not been abandoned, it will have its essential meaning, in which could not be overturned. It is an indispensable method still in existence for the good of humanity. We also hope that all human beings are able to recognize that in order to preserve the human race we also need to live in peaceful coexistence and compassion with one another. We also need to realize that constancy and change of conscience of the human race is peace, and only then we will be able to reach eternal constancy. Only the human race has the ability to change or remain constant, and continue to move forward. When each individual's mind is at ease and in balance it will manifest outwardly resulting in a universal brotherhood and an environment of peace around the world.

I Ching University popularizes the concept of a lifelong learning society; this can be demonstrated by the taiji picture in Figure 1. According to the Statistics Department of Ministry of Interior, R.O.C. (2015), under 21 years old (inclusive) population is the total population of $23.22 \%$ and above 21 years, old (inclusive) population is the total population of $76.78 \%$. Most people are around 22 year's olds after they graduate from University, they work until retirement at age 65 , and this is proximally $1,513,000$ people amounting to $62.44 \%$ of the total population. This shows that Taiwanese people under the age of 21 on average spend a quarter of their life in formal institutions of education. Therefore, about $62 \%$ of the populations currently from all fields of workplace are given work responsibilities and challenges of professional capabilities. 


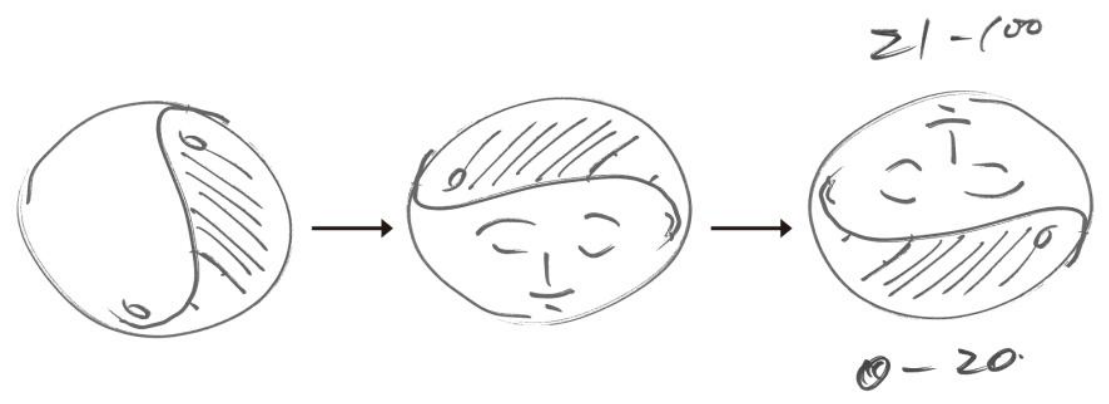

Figure 1: The lifelong learning in I Ching University by taiji figure

An individual adopting the knowledge and skills, which they received 21 years ago in formal school education to face another 60 years of life's challenges will not be enough. In the era of ever-unpredictability, may not be able to afford the social, economic and technological, environmental challenges and changes. Grand master Huan yuan pointed out that "Everyone study the I-Ching, behave and feel at ease; Everyone study the I-Ching, be healthy and carefree; Everyone study the I-Ching, do your work with satisfaction; Everyone study the I-Ching, every adult and child will be intelligent; Everyone study the I-Ching, every company and customer will feel secure; Everyone study the I-Ching, the family will be satisfied and of one mind; Everyone study the I- Ching, practice what you have learned and you will see the way; Everyone study the I Ching, the country's society will see peace." Based upon the "eight instructions", the I Ching University has constructed an education system for lifelong learning to meet the social environmental change in Taiwan. The education system consisted of five dimensions. There are faculty education, which raising and cultivating talented people, social education, which promoting community lifelong learning, student education, which cultivating younger generation, enterprise education, which strengthening the capability of organization sustainable development, and religious practice, which advocating the idea of grateful practice in the daily life. Additional, the cloud classroom in the International College of I Ching University has been constructed to promote Chinese culture, I-Ching and Feng Shui globally.

\section{Lifelong learning and learning motivation}

Looking at the global development of lifelong learning within China's ancient traditional culture there is a concept which states "You're never too old to learn". Lifelong learning is deeply rooted in Chinese society. Confucius was China's greatest and most important educator 2,500 years ago. His ideas about learning contained an abundance of contemporary ideas for lifelong learning. Confucius said: "Is it not pleasant to learn with constant perseverance and application? Illustrating that learning is an enjoyable activity. When I was fifteen, I became dedicated to my studies. When I was thirty, I could stand on my own. At forty, I was no longer confused. By fifty, I truly understood the ways of the world. At sixty, I could judge correctly whatever I heard. At seventy, I could do whatever my heart desired and not violate the dictates of morality" (The Analects, Weizheng). "Who in eager pursuit of knowledge forgets about food, who in the joy of attainment forgets his sorrows and does not perceive the coming of old age" (The Analects, Shu Er). Confucius considers that a person should study throughout his life, and have a practical and realistic approach to study. This is the attitude which a learned society should have regarding lifelong learning. Confucius advocated a learning process combining study, action, and thinking, starting an energetic principle of practice.

With regard to the concept of lifelong learning, the I Ching University founder Grand master Huan Yuan in the Year of JiawuWeixinShengjiao Puja Praying for Peace and Thanking the heavens (December, 2014) stated, "The sect is established by heaven and earth, which is called "Heaven" and "Yang". The principles were established by the sages for all the creatures of the world. The established principles are "Yin". Within heaven, earth and humans, humans stand between Yin and Yang. From conception until the age of sixty, we exist within yin on earth. After sixty years of age you surpass, and return to heaven, this is after age sixty-one. Therefore, living sixty years and not knowing how to correct one's self. When we are sixty years old, we still do not know all the rules, within there is a spirit. We are in the earth for sixty years; this is our body, heart, and soul. We are on earth haggling for fame and fortune, and complaining of a life full of love, hatred and sorrow. Sixty years, and not knowing how to correct one's self, or not correcting one's self and making it right, is six decades of erroneous thinking with bitterness and resentment. If we surpass sixty years of age, we should cherish it! Dying at sixty years of age is called a natural death, one can die at peace. If a person dies within sixty years without not knowing how to correct themselves, that is really a tragic life, a real pity. We come from the world of heaven, and once we enter a body, we have a form and color that allows our heart to feel pain, that is a real pity. Therefore, when facing the masses, we can say that dying at sixty years of age or above is dying without regret. 
In the year of KimiWeixinShengjiaoNinety-ninePuja (September,2013), Grand master Huan Yuan stated that "A turtle has a lifespan of 360 years, and some live even longer, but a turtle does not possess the faculty of thought, therefore, no thought of an intelligent existence. Humans have wisdom of life but a limited lifespan. The structure of the human body has a very subtle life intelligence that is wisdom. Therefore, we read countless of books, people who read more books and leave behind the true words, even our life's are brief, our life wisdom is boundless. When Sakyamuni Buddha reached 81 years of age, the number of heaven and earth, he returned to the great earth, returning the flesh back to the earth. Sakyamuni Buddha had used forty-nine years to expound Buddhist sutras, and to speak out the language of every person's soul, the wisdom of the spirit which constitutes life wisdom.

Research on what motivates adults to participate in education has revealed that the motivations of adult learners to participate are diverse. Houle (1961) focused on the research in adult learners participating in continuing education activities. As a result of the interviews, Houle identified three subgroups of adult learners: (1) the goal-oriented, (2) the activity-oriented, and (3) the learning-oriented. Goal-oriented adults pursue education as a means of achieving an objective such as taking a course to get a better job. Activity-oriented adults engage in learning for social reasons unrelated to the purpose or content of the activity, such as making friends and escaping unhappy relationships. The learning-oriented adults seek knowledge for its own sake. Hori and Cusack (2006) pointed out that older adults' attitudes toward aging are intricately connected to their motivation to participate in social activities. Those who hold positive attitudes are more willing to participate in social activities, and consequently, enjoy a richer lifestyle. The activity theory suggests that encouraging older adults to voluntarily join social activities is conductive to improving their satisfaction towards life.

However, taken together, Barbara McCombs (1991) suggested the following key characteristics of motivation and lifelong learning: (1) Learning and motivation to learn are natural human capacities in social contexts and relationships supportive of the learner and in content domains perceived as personally meaningful and relevant. (2) What and how much is learned is a function of each learner's unique views of themselves and learning process, including their goals, expectations, and interpretations of task requirements. (3) Insecurities and other forms of negative cognitive conditioning interfere with or block the emergence of individual's natural motivation to continually learn, grow, and develop in positive and self-determining ways.

\section{Life and Family Satisfaction}

In psychology, life satisfaction is conceptualized as an individual's "mental" (Tennant et al., 2007) or "subjective/psychological" well-being (Diener \& Biswas-Diener, 2008). Life satisfaction is defined as a general judgment or evaluation of a person on his or her own life (Pavot, Diener, Colvin, \& Sandvik, 1991). Weinstein \&Laverghetta (2009) pointed out that life satisfaction refers to the judgmental process whereby individuals compare their real-life situations and ideal situations. Studies have showed that life satisfaction is related to mood clarity (Extremera, Duran, \& Rey, 2009), self-esteem (Shek, 2005), perceived social support (Edwards \& Lopez, 2006), parental support (Suldo\& Huebner, 2006), material adjustment (Celik\&Tümkaya, 2012), religious beliefs, optimism (Acun-Kapikiran, 2012; Türküm, 2005), positive affectation (Busseri, Sadava, \&Decourville, 2007), self-compassion (Deniz, Arslan, Ozyesil, \&lzmirli, 2012, self-esteem (Taysi, 2000), and openness (Sheldon \&Hoon, 2007). Family satisfaction is defined as "the degree to which one is satisfied with one's family of origin and the constituent relationships embedded therein" (Carver \& Jones, 1992, p. 72). Rossiter and Pearce (1975) note that "satisfying relationships with other people are established through communication and that our ability to communicate well is important" (p. 3). The type of family communication, environment and daily conversations occurring among family members influence this perception of quality or satisfaction (Schrodt, Witt, \&Messersimth, 2008). Religious beliefs, values, and practices play a significant role in many family systems and in the development of adolescent worldviews (Smith, Denton, \& Regnerus, 2002). Individuals with strong religious faith reported higher levels of personal happiness (Ellison, 1991). Families who are a part of a religious organization often report increased closeness between parents and children (Snider, Clements, \& Vazsonvi, 2004). Family religious activities can facilitate better family interaction and provide opportunities to communicate desires, shared goals, and emotional healing between children and parents (Mahoney, Pargament, Tarakeshwar, \& Swank, 2001).

\section{Research hypotheses and model}

Based upon the viewpoints in the literature reviews the present study explores how adults perform during the high level of learning motivation in I-Ching study, and how it facilitates their life satisfaction and family satisfaction. Therefore, we propose the following hypotheses and research model: 
H1: The level of learning motivation in I-Ching study is positively correlated with life satisfaction.

$\mathrm{H} 2$ : The level of learning motivation in I-Ching study is positively correlated with family satisfaction.

To study the research questions, the following research model was developed.

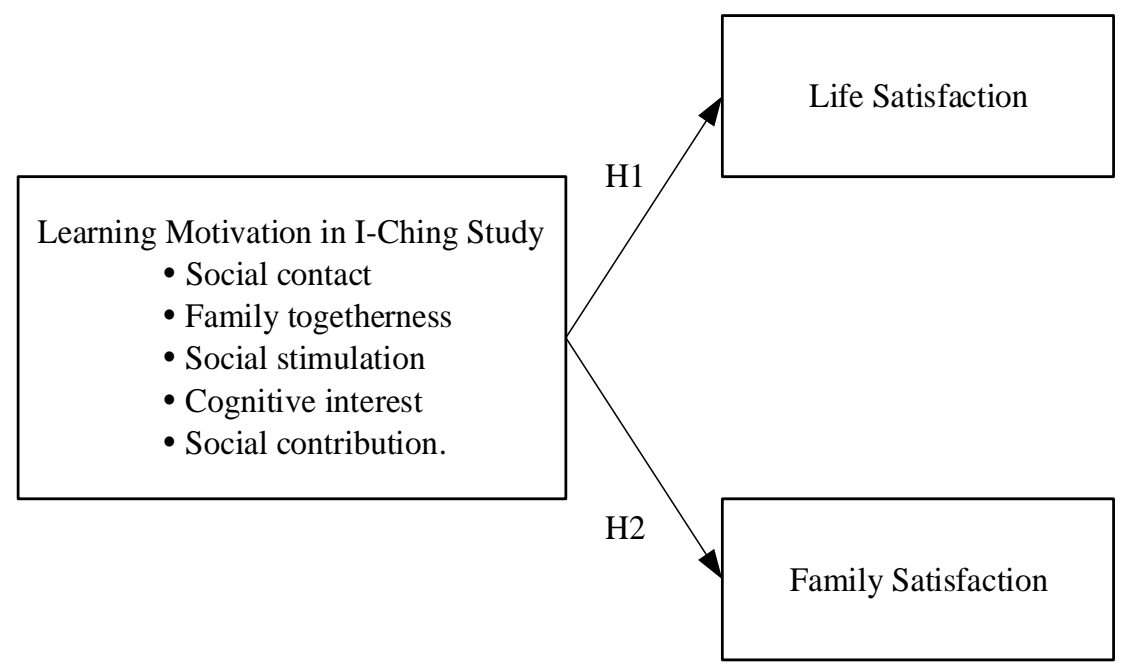

Figure 2: Research model

\subsection{Sample}

The sample participants for this study were students enrolled in the Weixin Master's Program at I Ching University. The Weixin Master's Program, established by Weixin Shenjiao (唯心聖教) with the purpose of cultivating future teachers for I Ching University. A total of 519 students agreed to take part in this study. A total of 473 participants returned the questionnaires with a response rate of $91.13 \%$.

\subsection{Measurement}

To assess the characteristics of the participants and their lifelong learning motivation for I-Ching learning, life satisfaction, and family satisfaction in I Ching University, the questionnaire was divided into four sections. Section one solicited socio-demographic information such as level of education, age, gender, and year of learning in Weixin master program. The second section of the questionnaire was a modified version of Boshier's 1991 Education Participation Scale (EPS, A-form) to measure participants' lifelong learning motivation in I Ching University. The modified final version of the EPS used in this study contained five dimensions: (1) social contact, (2) family togetherness, (3) social stimulation, (4) cognitive interest, and (5) social contribution. The third and fourth part of the questionnaire was to measure the perception of the participants' life satisfaction and family satisfaction. The SWLS (Diener, et al., 1985) was designed to measure individuals' overall satisfaction with their lives. The SWLS is composed of five items (e.g., "In most ways my life is close to my ideal"), which are rated on a 7-point scale from 1=strongly disagree to 7=strongly agree. The measurement of family satisfaction, was adopted from part of wellbeing questionnaire (Lu, Gilmour, Kao, Huang, 2006). Participants were asked to rate their family satisfaction on two questions: "My family life is very enjoyable" and "All in all, I am satisfied with my family".

\section{Research Findings}

\subsection{Gender, Age and Learning Motivation Analysis}

This study analyzed gender differences in learning motivation and found that men and women achieve significant differences in the family togetherness factor with an overall average score $(p<0.01)$, the other four factors were not significantly different. After inspection, we found that women's learning motivation and overall learning motivation scores for Family togetherness was significantly higher than men. Overall, the results show that women had higher learning motivation than men and more obviously within Family togetherness. 
Table 1: Examination of gender for learning motivation

\begin{tabular}{cccccccc}
\hline LM & Gender & $\mathrm{n}$ & Mean & S.D. & t-value & $d f$ & $p$-value \\
\hline \multirow{2}{*}{ Social contact } & Male & 266 & 3.679 & 0.620 & -1.838 & 445 & 0.067 \\
Family & Male & 181 & 3.790 & 0.624 & & & \\
togetherness & Female & 178 & 3.190 & 0.762 & $-2.743 * *$ & 438 & 0.006 \\
Social & Male & 264 & 2.592 & 0.752 & & & \\
stimulation & Female & 177 & 2.653 & 0.724 & -1.496 & 439 & 0.135 \\
Cognitive & Male & 268 & 4.047 & 0.541 & -0.803 & 447 & \multirow{2}{*}{0.423} \\
interest & Female & 181 & 4.092 & 0.638 & & & \multirow{2}{*}{0.208} \\
Social & Male & 267 & 4.157 & 0.430 & -1.261 & 443 & \\
contribution & Female & 178 & 4.214 & 0.527 & & & \multirow{2}{*}{0.006} \\
Total Score & Male & 251 & 3.514 & 0.458 & $-2.781 * *$ & 410 & 0.006 \\
of LM & Female & 161 & 3.644 & 0.471 & &
\end{tabular}

This study conducted a Pearson correlation analysis on age and learning motivation, it found that age and Family togetherness $(r=.127, p<.01)$ and Social stimulation $(r=.127, p<.05)$ have a significant relationship in learning motivation, indicates that older participants, in general, have more learning motivation in Family togetherness and Social stimulation. In addition, the higher the age, the higher the level of life and family satisfaction.

Table 2: The Pearson correlation analysis on age and learning motivation

\begin{tabular}{|c|c|c|c|c|c|c|}
\hline & $\begin{array}{l}\text { Social } \\
\text { contact }\end{array}$ & $\begin{array}{c}\text { Family } \\
\text { togetherness }\end{array}$ & $\begin{array}{c}\text { Social } \\
\text { stimulation }\end{array}$ & $\begin{array}{c}\text { Cognitive } \\
\text { interest }\end{array}$ & $\begin{array}{c}\text { Social } \\
\text { contribution }\end{array}$ & $\begin{array}{c}\text { Overall } \\
\text { LM }\end{array}$ \\
\hline Ages & -0.030 & $0.127^{* \ldots *}$ & $0.120^{*}$ & -0.037 & -0.086 & 0.044 \\
\hline \multicolumn{7}{|c|}{ Note: $* p<.05, \quad * * p<.01$} \\
\hline & & \multicolumn{2}{|c|}{ Life satisfaction } & \multicolumn{2}{|c|}{ Family satisfaction } & \\
\hline & Ages & \multicolumn{2}{|c|}{$.263 * *$} & \multicolumn{2}{|c|}{$.189 * *$} & \\
\hline
\end{tabular}

\subsection{Regression analysis on the effect of learning motivation on life satisfaction}

This study used seven scales to measure the degree of family and life satisfaction, the results show a (Mean $=4.738)$ in family satisfaction and a (Mean $=5.413$ ) for life satisfaction, both measures presented slightly above average levels of satisfaction (see Table 3).

Table 3: The descriptive statistics analysis of life and family satisfaction

\begin{tabular}{lcc}
\hline & Mean & S.D. \\
\hline Life Satisfaction & 4.738 & 1.262 \\
Family Satisfaction & 5.413 & 1.185 \\
\hline
\end{tabular}

This study used multiple hierarchical regression analysis to conduct a predictive analysis of learning motivation and life satisfaction. Gender and age had significant differences and significant correlations in learning motivation. The participant's gender and age were the control variables, and the five factors of learning motivation were the independent variables, and life satisfaction was the dependent variable. The results showed within model 1 , and model 2 of the learning motivation that social contact $(\beta=.147, p<.05)$, social stimulation $(\beta=.140, p<.05)$, cognitive interest $(\beta=.160, p<.01)$ and the overall learning motivation $(\beta=.390, p<.01)$, all could significantly predict life satisfaction (see Table 4). 
Table 4: Hierarchical multiple regression analysis between learning motivation and life satisfaction

\begin{tabular}{|c|c|c|c|c|c|c|}
\hline \multirow{3}{*}{$\begin{array}{c}\text { Dependent Variable } \\
\text { Model } \\
\end{array}$} & \multicolumn{6}{|c|}{ Life Satisfaction } \\
\hline & \multicolumn{3}{|c|}{ M1 } & \multicolumn{3}{|c|}{ M2 } \\
\hline & $S E$ & $\beta$ & $p$ & $S E$ & $\beta$ & $p$ \\
\hline \multicolumn{7}{|l|}{ Control Variables } \\
\hline Gender & .569 & -.044 & .318 & & & \\
\hline Age & .031 & $.231 * *$ & .000 & & & \\
\hline \multicolumn{7}{|l|}{ Predictors } \\
\hline Social contact & .088 & $.147^{*}$ & .019 & & & \\
\hline Family togetherness & .078 & .030 & .594 & & & \\
\hline Social stimulation & .094 & $.140 *$ & .012 & & & \\
\hline Cognitive interest & 152 & $.160 * *$ & .004 & & & \\
\hline Social contribution & .183 & .048 & .363 & & & \\
\hline Overall LM & & & & .022 & $.390 * *$ & .000 \\
\hline$R^{2}$ & & .223 & & & .211 & \\
\hline Adjusted $R^{2}$ & & .209 & & & .205 & \\
\hline$\Delta \mathbf{R} \mathbf{2}$ & & .161 & & & .149 & \\
\hline$F$-value & & $16.408 * *$ & & & $36.014 * *$ & \\
\hline VIF & & 1.416 & & & 1.020 & \\
\hline
\end{tabular}

\subsection{Regression Analysis on the effects of learning motivation on family satisfaction}

This study used multiple hierarchical regression analysis to conduct prediction analysis on the effects of learning motivation on family satisfaction. Gender and age had significant differences and significant correlations in learning motivation. The participant's gender and age were the control variables, and the five factors of learning motivation were the independent variables and family satisfaction was the dependent variable. The analysis results showed that within learning motivation model's 3 and 4 of social contact $(\beta=.151, p<.05)$, cognitive interest $(\beta=.159, p<.01)$ and overall learning motivation $(\beta=.276, p<.01)$ all could significantly predict family satisfaction (see Table 5).

Table 5: Hierarchical multiple regression analysis between learning motivation and family satisfaction

\begin{tabular}{|c|c|c|c|c|c|c|}
\hline \multirow{3}{*}{$\begin{array}{c}\text { Dependent Variable } \\
\text { Model } \\
\end{array}$} & \multicolumn{6}{|c|}{ Family Satisfaction } \\
\hline & \multicolumn{3}{|c|}{ M3 } & \multicolumn{3}{|c|}{ M4 } \\
\hline & $S E$ & $\beta$ & $p$ & $S E$ & $\beta$ & $p$ \\
\hline \multicolumn{7}{|l|}{ Control Variables } \\
\hline Gender & .227 & $.108^{*}$ & .023 & .229 & $.111^{*}$ & .019 \\
\hline Age & .012 & $.162 * *$ & .001 & .012 & $.135^{* *}$ & .004 \\
\hline \multicolumn{7}{|l|}{ Predictors } \\
\hline Social contact & .035 & $.151 *$ & .022 & & & \\
\hline Family togetherness & .031 & .010 & .866 & & & \\
\hline Social stimulation & .038 & .007 & .902 & & & \\
\hline Cognitive interest & .061 & $.159 * *$ & .007 & & & \\
\hline Social contribution & .073 & .045 & .418 & & & \\
\hline Overall LM & & & & .009 & $.276 * *$ & .000 \\
\hline$R^{2}$ & & 0.122 & & & 0.103 & \\
\hline Adjusted $\boldsymbol{R}^{2}$ & & 0.107 & & & 0.096 & \\
\hline$\Delta R^{2}$ & & 0.094 & & & 0.075 & \\
\hline$F$-value & & $8.030 * *$ & & & $15.583 * *$ & \\
\hline VIF & & 1.415 & & & 1.021 & \\
\hline
\end{tabular}




\section{Conclusion and Discussion}

Each individual is part of a family, and families make up the social and cultural systems. Different social and cultural systems have a mutual effect that influences world peace. Faced with highly competitive global trends, and financial, political, banking, economic, socio-cultural, and industrial unrest, and a rapidly changing environment. I Ching University begins its education from each body and soul by teaching the I-Ching and allowing individuals to have positive energy and knowledge of wisdom to adjust to the rapid changes in the environment and promote harmony within every family and social stability, thereby achieving the ultimate goal of world peace. This study tries to understand the different backgrounds and learning motivations of the participants, and what kinds of learning motivations can improve the lives of individuals and their family satisfaction. This is an important reference as to the enhancement of student learning and their ability to respond to the environment. First, this study found that the overall learning motivation of the I-Ching and Family togetherness motivation by women to be significantly higher than men, this shows that women have higher learning needs and hope that through learning the I-Ching they can enhance their ability to manage their household.

Second, the study found that the older participants' Family togetherness and Social motivation were also significantly higher, their family satisfaction and life satisfaction was generally better. This showed that older participants hoped that through the study of the I-Ching they could enhance their problem-solving ability to solve and manage family issues and expand their social networks increasing family satisfaction.

Third, the study found that the overall learning motivation can positively predict life satisfaction. Again we used the social contact, social stimulation, cognitive interest to study the predictive results of learning motivation which made it even clearer the results echoed by Türküm (2005) and Acun-Kapikiran (2012) which found that religion significantly enhance the individual's life satisfaction. In addition, from Hori and Cusack (2006) activity theory, which points out that participation in social network activities or learning activities can promote life satisfaction. Therefore, IChing University satisfies participant's interpersonal relations and the quest for knowledge actively promoting social education, enterprise education, and religious practice. Fourth, the study found overall that learning motivation can significantly predict family satisfaction. Past studies by (Ellison, 1991; Smith, Denton, \& Regnerus, 2002) have pointed out that religious beliefs can produce higher levels of happiness benefiting the family. I Ching University stresses the educational concept of the "unity of knowledge and practice" this concept is not only for the study of the I Ching but also to allow students all over the world to together, making friends, growing in spirit and maturing in wisdom, hoping students will learn the magnificence of the I-Ching and can have a happy family and be actively engaged in servicing society. Finally, we suggestions that future research explores the different learning effects, such as job satisfaction, physical and mental health, or explore the different groups, such as college youth and teachers.

\section{References}

Acun-Kapikiran, N. (2012). Positive and negative affectivity as mediator and moderator of the relationship between optimism and life satisfaction in Turkish university students. Social Indicators Research, 106, 333-345.

Boshier, R. (1991). Psychometric properties of the alternative form of the Educational Participation Scale. Adult Education Quarterly, 41 (3),150-167.

Busseri, M. A., Sadava, S.W., \&Decourville, N. (2007). A hybrid model for research on subjective wellbeing: Examining common and component-specific sources of variance in life satisfaction, positive affect, and negative affect. Social Indicators Research, 83, 413-445.

Carver, M. D., \& Jones, W. H. (1992). The family satisfaction scale. Social Behavior and Personality, 20, 71-84.

Celik, M., \&Tümkaya, S. (2012). The relationship between job variables of life satisfaction and marital satisfaction of lecturers.Ahi Evran Üniversitesi Kirsehir Egitim Fakültesi Dergisi (KEFAD), 13 (1), 223-238.

Delors, J. et al (1996).Learning: The Treasure Within. Paris: UNESCO Publishing.

Delors, J., \&Unesco. (1996). Learning, the treasure within: Report to UNESCO of the International Commission on Education for the Twenty-first Century. Paris: UNESCO Pub.

Deniz, M.E., Arslan, C. Özyesil, Z., \&Izmirli, M. (2012). Öz-Anlayis, yasamdoyumu, negativfvepozitifduygu: Türkvediğerüniversiteöğrencileriarasindabirkarsilastirma. Mehmet Akif

ErsoyÜniversitesiĔ̈itimFakültesiDergisi, 12(23), 428-446.

Diener, E. (1984). Subjective well-being.Psychological Bulletin, 95, 542-575.

Diener, E., Emmons, R. A., Larsen, R. J., \& Griffin, S. (1985). The satisfaction with life scale. Journal of Personality Assessment, 49 (1), 71-75.

Diener, E., \& Biswas-Diener, R. (2008). Happiness: Unlocking the mysteries of psychological wealth. New York, NY: Wiley/Blackwell. 
Diener, M. L., \& Diener McGavran, M. B. (2008). What makes people happy? A developmental approach to the literature on family relationships and well-being. In M.Eid\& R. J. Larsen (Ed.), The Science of Subjective Well-being (pp. 347-375). New York, NY: Guilford Press.

Edwards, L. M., \& Lopez, S. J. (2006). Perceived family support, acculturation, and life satisfaction in Mexican American youth: A mixed-methods exploration. Journal of Counseling Psychology, 53 (3), 279-287.

Ellison, C. G. (1991). An Eye for an Eye? A Note on the Southern Subculture of Violence Thesis. Social Forces, 69, 1223-1239.

Ellison, C. G. (1991). Identification and Separatism: Religious Involvement and Racial Orientations among Black Americans. The Sociological Quarterly 32(3), 477-494.

Ellison, C. G. (1991). Religious Involvement and Subjective Well-Being. Journal of Health and Social Behavior, 32, 80-99.

Ellison, C. G. (1991). Southern Culture and Firearms Ownership. Social Science Quarterly, 72 (2), 267-283.

Extremera, N., Duran, A., \& Rey, L. (2009). The moderating effect of trait meta-mood on perceived stress on life satisfaction. Personality and Individual Differences, 47, 116-141.

Holford, J., Sheila, R., Elisabet W., Judit, L. \& Guy, H. (2008). Patterns of Lifelong Learning: Policy and Practice in an Expanding Europe. Vienna: Lit Verlag.

Hori, S., \& Cusack, S. (2006). Third-age education in Canada and Japan: Attitudes toward aging and participation in learning. Educational Gerontology, 32, 463-481.

Houle, C. O. (1961). The inquiring mind. Madison, WI: University of Wisconsin Press.

Jagodzinski, W. (2009). Economic, social, and cultural determinants of life satisfaction: are there differences between Asia and Europe? Social Indicators Research, 92, 53-68.

Lai, S. L. (2009).Rescue unemployment global mobilization. Taiwan Labor Quarterly, 3 (17), 105-113.

Lu, L., Gilmour, R., Kao, S. F., \& Huang, M. T. (2006). A cross-cultural study of work/family demands, work/family conflict, and well-being: The Taiwanese vs. British. Career Development International, 11, 9-27.

Mahoney, A., Pargament, K. I., Tarakeshwar, N., \& Swank, A. B. (2001). Religion in the home in the 1980s and 1990s: A meta-analytic review and conceptual analysis of links between religion, marriage, and parenting. Journal of Family Psychology, 15, 559-596.

Master Huan-yuan (1985). I-ChingHeart Method. The Air Education Textbook Series I, Weixin Shengjiao I Ching University.

McCombs, B. L. (1991). Motivation and lifelong learning. Educational Psychologist, 26 (2), 117-127.

McCombs, B. L. (1991). Overview: Where have we been and where are we going in understanding human motivation? Journal of Experimental Education, 60 (1), 5-14.

Pavot, W., Diener, E., Colvin, R. C., \& Sandvik, E. (1991). Further validation of the Satisfaction with Life Scale: Evidence for the cross-method convergence of well-being measures. Journal of Personality Assessment, 57 (1), $149-161$.

Rossiter, C. M., Jr., \& Pearce, W. B. (1975). Communication personally: A theory of interpersonal communication and human relationships. Indianapolis, IN: Bobbs-Merril.

Schrodt, P., Witt, P. L., \& Messersmith, A. (2008). A meta-analytical review of family communication patterns and their associations with information processing, behavioral, and psychosocial outcomes. Communication Monographs, 75, 248-269.

Schunk, D. H., Pintrich, P. R., \&Meece, J. L. (2008). Motivation in education (3rd ed.). Upper Saddle River, NJ: Pearson Merrill Prentice Hall.

Shek, D. T. L. (2005). Economic stress, emotional quality of life, and problem behavior in Chinese adolescents with and without economic disadvantage. Social Indicators Research, 71 (1-3), 363-383.

Sheldon, K.M. \&Hoon, T. H. (2007). The multiple determination of well-being: independent effects of positive traits, needs, goals, selves, social supports, and cultural contexts. Journal of Happiness Studies, 8 (4), 565-592.

Soong, J. J. (2014). Political and Economic Analysis in the Anti-Chinese Riots in Vietnam, Straits Review Monthly, 282, 24-29.

Smith, C., Denton, M., \& Regnerus, M. (2002). Mapping American adolescent religious participation. Journal for the Scientific Study of Religion, 41, 597-612.

Snider, J. B., Clements, A., \&Vazsonvi, A. T. (2004). Late adolescent perceptions of parent religiosity and parenting processes. Family Process, 43, 489-493.

Statistics Department, Ministry of Interior, R.O.C. (2015). Retrieved from http://www.moi.gov.tw/stat/index.aspx

Suldo, S. M., \& Huebner, E. S. (2006). Is extremely high life satisfaction during adolescence advantageous? Social Indicators Research, 78, 179-203. 
Taysi, E. (2000).Benliksaygisiarkadaslardanveailedensağlanansosyaldestek: Üniversiteöğrencileriyleyapilanbircalisma (Yükseklisanstezi, Ankara Üniversitesi, Sosyal Bilimler Enstitüsü, Ankara). http://tez2.yok.gov.tr/adresindenedinilmistir.

Tennant, R., Hiller, L., Fishwick, R., Platt, S., Joseph, S., Weich, S., Stewart-Brown, S. (2007). The WarwickEdinburgh Mental Well-Being Scale (WEMWBS): Development and UK validation. Health and Quality of Life Outcomes, 5 (63),doi: 10.1186/1477-7525-5-63.

Türküm, A. S. (2005). Do optimism, social network richness, and submissive behaviors predict well-being? Study with a Turkish sample. Social Behavior and Personality, 33 (6),619-628.

Weinstein, L., \&Laverghetta, A. (2009). College student stress and satisfaction with life. College Student Journal, 43(4), 1161. 